\title{
Discussion on Ocean Concept of Marx and Engels from a Historical Perspective
}

\author{
$\mathrm{Xu} \mathrm{Li}$ \\ School of Marxism of Wuhan Business University \\ Wu Han, China \\ 1546687173@qq.com
}

\author{
Wang Xia \\ School of Marxism of Wuhan Business University \\ Wu Han, China \\ 251420228@qq.com
}

\begin{abstract}
Ocean is known as the cradle of human civilization. In the history of mankind, progress of the human society cannot be separated from the ocean. Marx and Engels had creatively expounded on their understanding of ocean from the perspective of world history. This paper starts from the development history, particularly the formation conditions and major connotations of capitalist society, combines the objective understanding of Marx and Engels about development of the human society, and expounds on development, evolution and essential attributes of their ocean concept. Meanwhile, the relationship between ocean development and a country's rise and wall is explored, considering the development history of the capitalist society. It is hoped that findings of this paper can provide potential insight into theoretical research of China's implementation of the strategy of strengthening the country via ocean development
\end{abstract}

Keywords-Marx; Engels; Concept of ocean; Capitalism

\section{INTRODUCTION}

Marx and Engels thought that humans are not independent beings but an indispensable part of nature, and that humans and nature are equals in this world. This constitutes scientific exposition of Marx and Engels on the relationship between humans and nature, and also the basis for formation of ocean concept of Marx and Engels.

\section{FORMATION CONDITIONS OF OCEAN CONCEPT OF MARX} AND ENGELS

\section{A. Age of Discovery and emergence of capitalism making formation of ocean concept of Marx and Engels possible}

Age of Discovery in the Western world laid the foundation for development of capitalism. In the 18th and 19th centuries, emergence of the Industrial Revolution led to deepening of industrialization of the capitalist society and promoted. The emerging capitalist countries were crying for more raw materials to develop their productivity. On the other hand, they faced the urgency to sell their industrialized products to the rest of the world to win more profits. During the process, capitalist countries represented by Britain embarked on the path of ocean trade. The traditional convoying policies could no longer satisfy needs of ocean trade. Capitalist countries notably Britain attempted to explore an easier development path, which was colonization. This change also aroused Marx's attention to the time-honored capitalist countries and to the emerging capitalist country, the United States. By analyzing the relationship between America and the Indian Ocean ship routes, finding that "handicraft workshops and production have made great progress." [1] Countries were interconnected with each other like never before. These phenomena prompted Marx to shape his own insight into the issue of ocean. As colonization spread, commodities of capitalist countries were sold worldwide to gradually form monopoly and accelerate accumulation of capitals. Therefore, Marx once said, "Because of large-scale railway construction and development of ocean shipping, the huge machines used to manufacture prime motors were produced." [2]

\section{B. Sustainable development of the Western maritime civilization providing the source for Marx and Engels to form ocean concept}

Western maritime civilization is a major part of Western civilization. Western ocean strategy originates from Greek. Hegel once said, "They surround the ocean, and a convenient traffic tool is developed. The rivers, lakes and oceans cannot be regarded as separation factors but as combination factors. England and Brittany, Norway and Denmark are all combined via the ocean. Similarly, the Mediterranean Sea is attributable for combination for three fourths of the land on the Earth. It is also the center of the world history. Greek, long being in the spotlight in the human society, is located here." [3] As humans knew more and more about the world, particularly after the advent of the Mechanization Era, Greek's outlook on nature was completely overthrown. Just as Hegel writes in The Philosophy of History, "The ocean not only invites humans to conquer it, but also encourages humans to pursue commercial profits." [4] Hegel's viewpoint of the ocean directly affected Marx's. However, Marx and Engel did not follow Hegel blindly but objectively examined the essence of capitalist society's development using practical methods. Finally, they coauthored the book entitled The Holy Family, in which Hegel's subjective idealism is criticized and historical materialism is expounded. This book provides the basis for formation of Marx and Engels's concept of ocean. With development of the capitalist society, Marx and Engels paid more attention to emerging capitalist countries, such as the United States, and kept on exploring the potential relationship between the ocean and these emerging capitalist countries' rapid development. "The Great Industry built a world market for America. The world market promoted large-scale development of commerce, maritime industry, and land traffic 
tools. The latter in turn accelerated expansion of the industrialization scope. Meanwhile, development of industry, commerce and maritime industry fueled maturity of the capitalist class, which kept on increasing their capitals and pulled all the other classes left behind by the Middle Ages behind them." [5] Nevertheless, it was not until publication of The Communist Manifesto in 1848 that Marx and Engels's ocean concept was formally shaped.

\section{BASIC CONNOTATION OF MARX AND ENGELS’ OCEAN CONCEPT}

Marx and Engels objectively analyzed the development history of capitalism from generation to thriving and finally to extinction, finding that development of capitalism has never been separated from the ocean. To say that ocean is connected with the birth and death of capitalism like a bond is less exact than to say that the ocean is connected with the capitalist market and the world market like a bond. Age of Discovery provided an extensive market for the capitalist world overnight and quickly connected different parts of the world together. All this objectively stimulated development of the commodity economy and sped up overseas colonization of capitalist countries. Marx and Engels took development of the capitalist society and the ocean as an integrated whole. Under the guidance of the historical materialism, Marx and Engels built a systematic ocean concept.

\section{A. Essential attributes of ocean reflecting the relationship between humans and nature}

1) Philosophical basis of Marx and Engels's ocean concept originating from their exposition on concept of nature

"Marx's Manuscript of Economics and Philosophy in 1844 and An Outline about Feuerbach, Engels's The Condition of the Working-class in England and Outline of Critique of Political Economics, and Marx and Engels' co-authored books, such as The Holy Family and The German Ideology have all demonstrated a mature understanding of nature." [6] In these books, nature is depicted as "personalized nature in which human practice undergoes." This provides the philosophical basis for formation of their ocean concept. Marx and Engels gave up the unscientific element in Hegel's and Feuerbach's opinions, thinking that nature means not just a pure natural world, but the nature related to humans and involved with human activities. Existence of the natural world lays the foundation for humans' living, proliferation and development. Without the natural world, the human society cannot acquire production materials necessary to their development. After appearance of humans, humans change nature, turning nature into "personalized nature."

2) Limited ocean resources making establishment of the sustainable development concept necessary

Earlier in the 8 B.C., the Greeks had already realized the precious value of ocean resources. Hegel once pointed out, "The Mediterranean Sea exists as the heart of the old world, for it provides the condition for formation of the old world. Without the Mediterranean Sea, the 'world history' will not exist." [7] Throughout the world, the early capitalist countries had undergone ocean wars, aiming at occupying maritime resources. Therefore, Marx stated that "people are not questioning why the land is easier to occupy than ocean and air but they want to know what right can turn the fortune into their own." [8] Marx held that the ocean is a part of nature and emphasized the subjective role of humans. Humans should understand the role of the ocean in development of capitalism from the perspective of human's practice. At the same time, Marx and Engels deepened the relationship between humans and the ocean as well as the relationship between humans and nature. To survive, humans should keep on developing natural resources, of course including the ocean. During the process of development, humans can grasp rules of ocean and make use of these rules to support their own development needs. Nevertheless, it should be noted that maritime resources are by no means inexhaustible. Hence, maritime resources have become resources of strategic importance which capitalist countries contend for. At the same time, nature is not a slave of humans. This requires humans to develop nature following a sustainable approach. In fact, sustainable development of nature is equal to sustainable development of humans.

\section{B. Ocean as a material carrier of capitalist development}

\section{1) Coastal areas as the cradle of capitalism}

In the opinion of Marx, that capitalism originates from coastal areas is an irresistible development trend. Development of the commodity economy will definitely contribute to prosperity of trade. The coastal areas are an optimal place for commodity trade. "Before the direct path towards India was discovered, Constantinople was the center of extensive trade. Even now, though India's products are transported to Europe via Persia, Turan and Turkey through land transportation, the harbor of Turkey still plays an important role in transporting goods between inlands of Europe and Asia." [19] Particularly after the American Continent was discovered, development of capitalism was objectively stimulated, which in turn gave rise to the Industrial Revolution and formed the basic profile for the capitalist surplus value.

\section{2) Ocean as the material undertaker of primitive accumulation of capitals}

By studying the development history of capitalism, Marx deeply realized the essence of primitive accumulation of capitalism. The enclosure movement and the overseas colonization were just external reflections and realization processes of capital's primitive accumulation. In essence, they were an inevitable outcome of the capitalist production means. Just as Marx once said, "Different factors affecting primitive accumulation are distributed in Spain, Portugal, Netherlands, France and Britain in the time sequence, respectively." [10] Therefore, after the Age of Discovery, prosperity of ocean trade objective sped up rapid development of capitalism. In the face of the attractive profits, capitalists unremittingly upgraded their production techniques, improved their productivity, and relied on the material carrier, ocean, to seize more resources from different parts of the world. Additionally, they introduced capitalist production means to the rest of the world, thus building an unprecedented status for the capitalist class. When speaking of sea transportation, Engels said, "The desire to seek gold in other parts of the world, though realized in the feudal or semi-feudal form, was in essence incompatible with feudalism. 
Agriculture was the basis of feudalism. The feudalist ruler waged wars in foreign countries so as to gain more lands. Besides, the maritime industry was a definite capitalist industry, which could imprint its anti-feudal attribute to every modern fleet." [11]

\section{Ocean, the lifeline of overseas trade, accelerating the formation of world market}

1) Sea transportation becoming a major transportation mode of international trade, leading to continuous expansion of the overseas trade scope

The Age of Discovery starting in 1492 officially unveiled the world history. The swiftly expanding overseas trade fueled development of sea transportation. In Marx's era, air transportation had not yet appeared, so goods were mainly transported by sea. As a result, sea transportation became a major form of international trade transportation. With largescale construction of railways, inlands were growingly connected with oceans. The world trade gradually got rid of old ship routes and the Silk Road, making swift expansion of the trade scope possible. In order to meet needs of the world market, the capitalist class started to vigorously develop the shipping industry for their convenience of fortune accumulation during overseas colonization and international trade. Take Britain for example. "In the late 19th century, the total tonnage of commercial ships accounted for $81.2 \%$ of the world total. Britain maintained its hegemony in the world's ship-building industry in the late 19th century and the early 20 th century. Under the prerequisite of meeting its domestic needs, Britain also exported commercial ships to countries, including Italy. Likewise, the United States built many canals on the basis of its rivers. This also fueled prosperity of its shipping industry." [12]

2) Ocean as an important factor of the world market formation

Before the Age of Discovery, the regional economy dominated. The most famous one was the East Asia Economic Circle with China's Ming Dynasty (1368-1644) at the center. With development of capitalism, capitalists traveled across oceans to seek a broader world market. These problems were effectively addressed through constant improvement of maritime technologies and ship-making technologies. The traditional regional economy was gone, and the world market gradually formed. In order to seek a broader world market, the capitalist class headed towards colonization and enriched their labor forces on their colonies through slave trade. Consequently, colonies became targets of colonizers to dump their commodities. Therefore, almost every country has been engulfed into the flood of world history, either passively or actively. Regionally, economy of different countries and regions has been integrated into a whole, deepening their mutual connection and stimulating multiethnic integration. This suffices to show the ocean as a bridge to development of the world market.

\section{Maritime power becoming an indicator of a country's prosperity}

Development of capitalism led to continuous improvement of Marx's theoretical system and growing maturity of his ocean concept as well. Further research of Marx and Engels showed that deepening of colonization transferred capitalism to imperialism. In order to maintain control of colonies and develop more colonies, capitalist countries vigorously developed their maritime armed forces and even waged wars to seek their control of the ocean. A country's industrialization largely depended on prosperity of sea trade. Therefore, a country's maritime power changes could directly reflect changes of the country's comprehensive strength or even directly demonstrate the country's industrial basis. All this was decided by the logic that the economic basis decides the superstructure. Changes of a country's maritime power are in essence changes of the country's productivity level. All these were outcomes of capital operation.

\section{CONCLUSIONS}

Marx and Engels's ocean concept is a historical concept, which transcends the boundary between the land and the ocean in the narrow sense. By putting the concept of ocean in the development process of the capitalist society, Marx and Engels connected the ocean with a country's rise and fall to not only deepen the understanding of capitalist development, but also reveal changes of maritime power and general rules of a country's rise and fall. To sum up, Marx and Engels' ocean concept enables readers to gain a better understanding of China's modern history. By taking history as a mirror, the Chinese people can better safeguard the national maritime rights, and combine development of maritime economy with expansion of the navies to fully implement the strategy of strengthening the country through ocean development.

\section{REFERENCES}

[1] Collected Works of Marx and Engels. Vol. 3, Beijing: People's Publishing House, 1956: p64.

[2] Collected Works of Marx and Engels. Vol. 44, Beijing: People's Publishing House, 2001: P441.

[3] Hegel (Germany). The Philosophy of History. Translated by Z. S. Wang. Shanghai: Century Library of Century Publishing Group of Shanghai, 2006, p74.

[4] Hegel (Germany). The Philosophy of History. Translated by Z. S. Wang. Shanghai: Century Library of Century Publishing Group of Shanghai, 2006, p81.

[5] Collected Works of Marx and Engels. Vol. 4, Beijing: People's Publishing House, 1958: p467.

[6] Y. C. Zhou. Natural Theories and Modern Era. Shanghai: Shanghai People's Publishing House, 1988, p92.

[7] Hegel (Germany). The Philosophy of History. Translated by Z. S. Wang. Shanghai: Century Library of Century Publishing Group of Shanghai, 2006, p74.

[8] Collected Works of Marx and Engels. Vol. 2, Beijing: People's Publishing House, 1957: p54.

[9] Collected Works of Marx and Engels. Vol. 12, Beijing: People's Publishing House, 1998: p16.

[10] Collected Works of Marx and Engels. Vol. 44, Beijing: People's Publishing House, 2001: p861.

[11] [Collected Works of Marx and Engels. Vol. 4, Beijing: People's Publishing House, 2009: p217.

[12] Z. X. Song \& K. Fan. History of World Economy. Vol. 2, Beijing: Economic Science Press, 1989, p200. 